\title{
Isozymic variability in a Brazilian collection of annatto (Bixa orellana L.)
}

\author{
Jane Fiuza Rodrigues Portela de Carvalho(1), Ingrid Peters Robinson ${ }^{(2)}$ and Acelino Couto Alfenas ${ }^{(3)}$
}

\begin{abstract}
(1)Instituto Agronômico do Paraná, Laboratório de Biotecnologia, CEP 86047-902 Londrina, PR, Brazil. E-mail: jfiuza@iapar.br (2)State University of New York, University at Albany, Biological Sciences, NY12222, USA. E-mail: irobins@csc.albany.edu (3)Universidade Federal de Viçosa, Dep. de Fitopatologia/Bioagro, CEP 36571-000 Viçosa, MG, Brazil. E-mail: aalfenas@ufv.br
\end{abstract}

\begin{abstract}
The objectives of this work were to optimize the isozyme electrophoresis technique for Bixa orellana, and use isozyme markers for a preliminary survey on the genetic variability in Brazilian annatto germplasm accessions. Collection consisted of seed samples from sixty open pollinated trees, representing two Northern and four Southern geographic provenances. The extraction, electrophoresis, and interpretation of annatto isozymes are described. Three out of the twenty-one identified isozyme loci were polymorphic in the collection. The percentage of polymorphic loci $(\mathrm{P}=21.05)$ and the expected heterozygosity in annatto $\left(\mathrm{H}_{\mathrm{T}}=0.064\right)$ were low, compared to other tropical woody species. A UPGMA phenogram, constructed with Nei's genetic distances, clearly separated the germplasm provenant from North and Central Brazil. Variability was significantly higher among the accessions from Maranhão. A sharp genetic differentiation was detected between accessions from Maranhão and Pará States, despite their geographical proximity. The distinctive isozyme polymorphism, observed in the accessions from Maranhão, together with reports on local morphological heterogeneity in annatto fruit shape, color, and pubescence, calls for more detailed genetic and taxonomic investigation.
\end{abstract}

Index terms: germplasm, lipstick plant, genetic variability, allozyme, phenogram.

\section{Variabilidade isoenzimática em uma coleção brasileira de urucum (Bixa orellana L.)}

\begin{abstract}
Resumo - Os objetivos deste trabalho foram: otimizar a técnica de eletroforese de isoenzimas para Bixa orellana, e usar marcadores isoenzimáticos para um estudo preliminar da variabilidade genética, presente em uma coleção de germoplasma de urucum. Foi estudada uma coleção de amostras de sementes oriundas de 60 indivíduos de polinização aberta, que representam duas procedências do Norte e quatro do Sul do Brasil. São descritas a extração, a eletroforese e a interpretação de isoenzimas de urucum. Três, dos vinte e um locos isoenzimáticos identificados, foram polimórficos na coleção examinada. A porcentagem de locos polimórficos $(\mathrm{P}=21,05)$ e a heterozigosidade esperada em urucum $\left(\mathrm{H}_{\mathrm{T}}=0,064\right)$ foram baixas, em comparação com outras espécies arbóreas tropicais. O dendrograma UPGMA, construído com base nas distâncias genéticas de Nei, diferenciou claramente as procedências de urucum do Norte, daquelas oriundas do Brasil Central. A variabilidade foi significativamente superior na procedência Maranhão. Uma pequena diferenciação genética foi detectada entre os acessos do Maranhão e do Pará, apesar da proximidade geográfica. O polimorfismo isoenzimático diferenciado, observado no germoplasma procedente do Maranhão, somado a relatos de heterogeneidade morfológica local com relação à forma, à cor e à pubescência dos frutos de urucum, sugerem uma investigação genética e taxonômica mais detalhada dessa espécie.
\end{abstract}

Termos para indexação: germoplasma, variabilidade genética, urucum, aloenzima, dendrograma.

\section{Introduction}

Annatto (Bixa orellana L.), called urucum in Brazil, is a widespread species in the Neotropics. It belongs to the native flora of Brazil, Paraguay, Colombia, Dominican Republic, Haiti, Trinidad, Mexico, Panama and Hawaii (Ramalho et al., 1987). The original geographic range of annatto in Brazil includes Northern and Northeastern parts of the country, encompassing the States of Amazonas, Pará, Maranhão, Piauí, Ceará, Paraíba and Bahia (Lingerfelt, 1984). The reddishyellow pigment coating annatto seeds are still used by Brazilian indigenous people to paint their bodies, and to dye their breechcloths (Plotkin, 1993).

The annatto pigment contains bixine and norbixine, valuable natural colorants used for industrial food and 
beverages, cosmetics, pharmaceutical products, and as natural dyes for textiles (Póvoa, 1992). Restrictions imposed on the use of synthetic additives in the food industry have intensified the investigation on biochemical properties of annatto plants and seeds (PrenticeHernandez \& Rusig, 1992), and raised interest in the evaluation of genetic variability in the species.

Genetic improvement programs of annatto began in Brazil in the late 1980's, and consist mostly of field trial comparing germplasm of different geographic provenances (Villares et al., 1992). Selection is practiced to enhance seed production and to raise their pigment content to levels above $2.5 \%$, the commercial base line for export quality. On a plantation scale, where trees grew at spaces of about $5 \mathrm{~m}$, mature specimens yield 80-100 kg ha-1 of seed (Heywood, 1993). Annatto breeding efforts also focus on the search for genetic resistance to mildew in plants (Morais et al., 1999; Santos et al., 2000).

Concerns about the conservation of genetic resources of the species have stimulated the establishment of seed collections and ex situ genebanks of annatto in Brazil (Morais et al., 1999). Germplasm collections of annatto are presently maintained by Embrapa, Brazilian Agricultural Research Corporation, and by private collectors.

The objectives of this work were to optimize the isozyme electrophoresis technique for B. orellana, and use isozyme markers for a preliminary survey on the genetic variability in Brazilian annatto germplasm accessions.

\section{Material and Methods}

The annatto seeds planted for this study were obtained from germplasm collections maintained by Embrapa Amazônia Oriental (CPATU, 12 progenies), Embrapa Cerrados (CPAC, 10 progenies from each Mato Grosso 1, Mato Grosso 2, Planaltina, DF and Campinas, SP), and from a private collection from Maranhão State [progenies from Itapiracó (3), Vassoural (2), Sítio Grande (2) and Maiobá (1)], in Northeastern Brazil. A progeny is a family array obtained from seeds of a given tree. The original accessions were single trees, identified at distinct locations within each specified region. Seeds from each open-pollinated tree were harvested and multiplied in field trials in CPAC and CPATU. Four accessions listed for Maranhão were non- multiplied seed, obtained directly from the collector; these accessions were pooled for genetic analysis to match the number of progenies representing the other geographic regions. Five seedlings per progeny were used for isozyme electrophoresis. A total of 300 seedlings were examined in this study.

Starch gel electrophoresis was performed on enzyme extracts from fresh unblemished leaves rinsed in distilled water. The leaves were harvested when seedlings had 3-4 expanded leaflets. After removing the central vein, one gram of leaf tissue was homogenized in $1.5-2 \mathrm{~mL}$ of ice-cold extraction buffer. The porcelain mortars used in the procedure were cooled in a freezer $\left(-20^{\circ} \mathrm{C}\right)$ before enzyme extraction. Just before homogenization, $100 \mathrm{mg}$ PVPP (polyvinyl-polypyrrolidone) were added to the leaf sample. The slurry was covered with a square $(5 \times 5 \mathrm{~cm})$ of single layered tissue paper to filter the protein extract, which was then absorbed in Whatman 3MM Chromatography-paper wicks (12x5 mm), and stored in microfuge tubes at $-85^{\circ} \mathrm{C}$ until use for electrophoresis (Alfenas et al., 1998).

Isozymes were separated in horizontal 13\% starch gels. Five gel and electrode buffer systems were tested: 1) citric acid (0.04 M) N-(3-aminopropy) morfoline pH 7.1 (Clayton \& Tretiak, 1972); 2) Tris (0.076 M) citric acid (0.005 M) pH 8.6 (Poulik, 1957); 3) Tris (0.015 M) citric acid (0.0038 M) pH 7.5 (Scandalios, 1969); 4) Tris $(0.065 \mathrm{M})$ citric acid $(0.001 \mathrm{M}) \mathrm{pH} 8.1$ (Moran \& Bell, 1983); 5) Histidine- $\mathrm{HCl}$ (0.005 M) NaOH (4 M) pH 7.1 (Hakim-Elahi, 1980). Starting with the most anodal form, loci and alleles were designated sequentially by numbers and by letters, respectively. Migration rates of bands in the gel were expressed in percentage of their distance to the running front. The examined isozyme systems are listed in Table 1.

Genotypic data were analyzed with the computer package BIOSYS-1 (Swofford \& Selander, 1981). The observed (direct count) and expected frequencies of heterozygotes were calculated for each locus, and averaged over loci, based on Hardy-Weinberg equilibrium (Hartl \& Clark, 1997). Multilocus genetic comparisons were made by computing Nei's (1978) unbiased genetic distances between pairs of accessions. The distance matrix was used to construct an unweighted pair group cluster analysis (UPGMA) phenogram, to graphically illustrate the similarity among accessions (Sneath \& Sokal, 1973). 


\section{Results and Discussion}

The five electrophoresis buffer systems were given scores, ranging from 3 to 0 , denoting their suitability for each investigated annatto enzyme (Table 1). Twelve out of eighteen examined isozyme systems produced welldefined electrophoretic bands, showing strong enzymatic activity. Based on these results, the morpholine-citrate buffer (pH 6.1/7.1) was chosen for ADH, 6-PGDH, GDH, IDH, LAP, MDH, ME, and SKDH. The Triscitrate/ lithium borate buffer ( $\mathrm{pH}$ 8.1/8.6) was chosen for DIA and SOD. Four isozyme systems, ADH, ME, ACP and LAP, produced good zymograms, under a broad range of electrophoretic conditions.

Diffuse spots or smears of enzymatic activity were obtained in the gels stained for $\alpha$-EST, PGI, GOT, and PO. No PGM activity at all was obtained from annatto enzyme extract using the five selected buffer combinations. Staining different horizontal slices in the gel (from the top layer to the bottom) made no difference in the results. Figure 1 shows the zymograms produced by the nine monomorphic enzyme systems in annatto collection. Given to absence of variation in the systems, the genetic interpretation of these zymograms was based on the most common findings reported for other plant species. The MDH and ME zymograms were

Table 1. Isozyme systems examined in annatto, and scores assigned to the electrophoresis buffers ${ }^{(1)}$.

\begin{tabular}{lllllll}
\hline Enzyme & EC $^{(2)}$ & \multicolumn{5}{c}{ Buffer $^{\text {system }}{ }^{(3)}$} \\
\cline { 3 - 7 } & & 1 & 2 & 3 & 4 & 5 \\
\hline Alcohol dehydrogenase (ADH) & 1.1 .1 .1 & 3 & 0 & 3 & 1 & 3 \\
Diaphorase (DIA) & 1.8 .1 .4 & 2 & 1 & 2 & 3 & 2 \\
Malic enzyme (ME) & 1.1 .1 .40 & 3 & 2 & 2 & 2 & 3 \\
Esterase ( $\alpha$-EST) & 3.1 .1 .1 & 2 & 2 & 2 & 2 & 1 \\
Acid phosphatase (ACP) & 3.1 .3 .2 & 2 & 3 & 2 & 1 & 3 \\
Phosphoglucomutase (PGM) & 2.7 .5 .1 & 0 & 0 & 0 & 1 & 1 \\
6-phosphogluconate dehydrogenase (6-PGDH) & 1.1 .1 .44 & 3 & 2 & 2 & 2 & 2 \\
Phosphoglucose isomerase (PGI) & 5.3 .1 .9 & 2 & 2 & 2 & 2 & 2 \\
Glutamate dehydrogenase (GDH) & 1.4 .1 .3 & 1 & 2 & 2 & 2 & 0 \\
Glutamate-oxaloacetate transaminase (GOT) & 2.6 .1 .1 & 2 & 0 & 2 & 2 & 0 \\
Isocitrate dehydrogenase (IDH) & 1.1 .1 .42 & 3 & 2 & 2 & 1 & 2 \\
Leucina aminopeptidase (LAP) & 3.4 .11 .1 & 3 & 2 & 3 & 3 & 3 \\
Malate dehydrogenase (MDH) & 1.1 .1 .37 & 3 & 2 & 2 & 2 & 2 \\
Peptidase (PEP) & $3.4 .1 .-$ & 2 & 2 & 2 & 3 & 0 \\
Peroxidase (PO) & 1.11 .1 .7 & 1 & 2 & 2 & 0 & 1 \\
Superoxide dismutase (SOD) & 1.15 .1 .1 & 2 & 1 & 1 & 3 & 2 \\
Shikimic dehydrogenase (SKDH) & 1.1 .1 .25 & 3 & 2 & 0 & 2 & 2 \\
\hline
\end{tabular}

${ }^{(1)} 0$ : absence of enzymatic activity; 1 : low enzymatic activity; 2 : bad resolution in the formed bands; 3: good resolution in the formed bands. (2)Enzyme Commission, which established the international codes of enzyme identification. (3) 1 : Citric acid (0,04 M) N-(3-aminopropy) morfoline pH 7.1 ; 2 : Tris $(0.076 \mathrm{M})$ citric acid $(0.005 \mathrm{M}) \mathrm{pH}$ 8.6; 3: Tris $(0.015 \mathrm{M})$ citric acid $(0.0038 \mathrm{M}) \mathrm{pH} 7.5$; 4 : Tris $(0.065 \mathrm{M})$ citric acid (0.001 M) pH 8.1; 5: histidine- $\mathrm{HCl}$ (0.005 M) NaOH (4 M) $\mathrm{pH} 7.1$. indistinguishable with used protocol. Both produced two electrophoretic zones and three bands. The most anodal zone stained lighter. Bands were attributed to three monomorphic loci. A secondary band consistently followed the position of main LAP enzyme in the gel. The staining intensity of this LAP band was always weaker, independently by of the concentration of the leaf extract. Secondary bands often result from posttranslation modifications of the isozyme molecules, but multiple LAP bands have been associated with low enzyme-substrate specificity in some plant species (Weeden \& Wendel, 1989). The SKDH zymogram consisted of three bands, whose two sharper ones were interpreted as representing two loci. To be conservative in the interpretation of invariable electrophoretic forms, the most cathodal and lighter SKDH band was not included in the genetic analysis. GDH, IDH, ACP and $\mathrm{ADH}$ produced uniform single banded zymograms in annatto.

Polymorphism was observed in four out of eight loci identified for 6-PGDH, SOD and DIA. Six multilocus 6-PGDH phenotypes were distinguished. The fastest band in the 6-PGDH zymograms $\left(\mathrm{R}_{\mathrm{f}}=0.25\right)$ comprises a monomorphic locus, 6-Pgdh-1. The band representing the fast allele $(a)$ of 6 -Pgdh-2 shares this migration distance (Figure 1). The three 6-Pgdh-2 phenotypes encountered in the collection are typical of a dimeric enzyme. However, the phenotypes attributed to $a b$ and $b c$ heterozygotes at 6 -Pgdh-3 were two-banded. Putative homozygote genotypes $c c$ and $b b$ of 6-Pgdh-3, but not $a a$, were represented in the collection. A strong correlation was observed between genotypes $a a, a b$ and $b b$ at 6-Pgdh-2, and genotypes $b b, b c$ and $c c$ at 6-Pgdh-3 locus, respectively. Correspondence between these genotypes was absolute in the CPATU collection $(\mathrm{N}=60)$. This strong correlation simulated patterns caused by secondary bands (phenotypes 4, 5 and 6). Correlation between genotypes was lowest in accessions from Maranhão. Phenotypes 4 and 6 were rare collection-wide, each appearing only twice in the Campinas and Planaltina accessions, respectively. A reasonable explanation for the correlated genotypes would be close linkage between the two 6-PGDH loci. This hypothesis must be verified, by means of controlled crosses, between plants with phenotype 2 and 4, or between 3 and 4 , assuming that phenotype 4 is double heterozygote. 
Three multilocus SOD phenotypes were observed (Figure 1). Sod-1 and Sod-3 were monomorphic in this collection. Locus Sod-1 separates clearly as a single banded electrophoretic zone $(\mathrm{Rf}=0.57)$, but allele $b$ of Sod-2 overlaps with the position of the invariable Sod-3 band. The heterodimer shown in phenotype 3, together with the variation in staining intensity of the most cathodal band, shown in phenotypes 1 and 2, confirms that SOD of annatto is a dimeric enzyme with overlapping activity zones in the gel. The Sod-2 locus was polymorphic in the accessions from Maranhão, with two segregating alleles.

Two loci of DIA were identified in annatto, Dia-1 being monomorphic $(\mathrm{Rf}=0.40)$. The other three bands in the DIA phenotypes shown in Figure 1 are evenly spaced, about $0.5 \mathrm{Rf}$ units apart. These bands were interpreted as representing the alleles $a, b$ and $c$ found at locus Dia-2. Desirable test-crosses to examine the segregation at Dia-1 would be between plants with phenotypes $1 \times 3$, and $3 \times 4$, both expected to produce a 1:1 phenotypic ratio in the progeny.
The allelic frequencies for the isozyme loci in annatto accessions are listed in Table 2. The last column represents the twelve monomorphic loci, with their respective bands designed as allele $a$. Table 3 shows the average number of alleles at polymorphic loci (A), percentage polymorphic loci $(\mathrm{P})$, expected $\left(\mathrm{H}_{\mathrm{T}}\right)$ and observed heterozygosity (Het), given for each locus, accession, and for the entire collection. 6-Pgdh-3 was the overall most variable locus $(\mathrm{H}=0.453)$, contrasting with Sod-2 $(\mathrm{H}=0.128)$. A and $\mathrm{P}$ values were both highest in Maranhão due to variability at Dia-2 and Sod-2.

When plants that belong to different natural populations are pooled and analysed as a single group, such as accessions in a germplasm collection, the expected heterozygosity is generally higher than the observed count of heterozygote genotypes, as a consequence of the 'Wahlund effect' (Hartl \& Clark, 1997). For this reason, the expected heterozygosity exceeded the average count of heterozygote genotypes in five out of six accessions, with an even higher excess ( $t$ test, $\mathrm{P}<0.0$ ) in the whole collection $\left(\mathrm{H}_{\mathrm{T}}=0.064\right.$; Het $\left.=0.039\right)$. Both
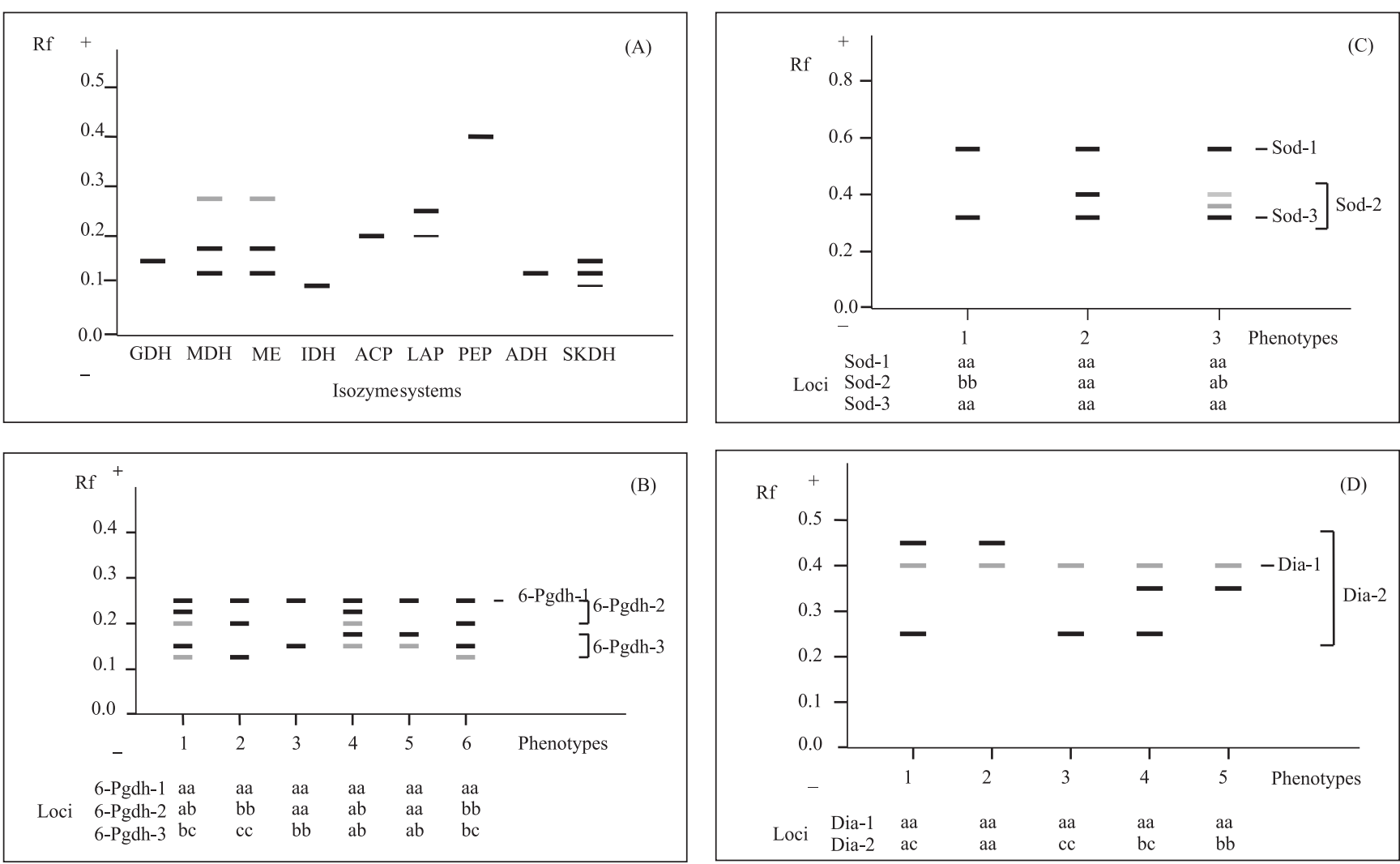

Figure 1. Zymogram of the monomorphic isozyme systems in annatto (A); diagrams and genetic interpretations of the zymograms of 6-phosphogluconate dehydrogenase (6-PGDH) (B); superoxide dismutase (SOD) (C); and diaphorase (DIA) (D) in annatto. 
the polymorphic index $(\mathrm{P}=20.05)$ and the heterozygosity estimated in annatto $\left(\mathrm{H}_{\mathrm{T}}=0.064\right)$ were lower than reported for other woody species: $\mathrm{P}=27.60$ and $\mathrm{H}_{\mathrm{T}}=0.131$ (Hamrick \& Loveless, 1986); $\mathrm{P}=46.1$ (Agarwal et al., 2001); $\mathrm{H}_{\mathrm{T}}=0.242$ (Lee et al., 2002); $\mathrm{P}=49.0$ and $\mathrm{H}_{\mathrm{T}}=0.22$ (Guo et al., 2003); $\mathrm{P}=36.58$ and $\mathrm{H}_{\mathrm{T}}=0.11$ (Sharma et al., 2004).

Using the variance components estimated with BIOSYS program, heterozygosity $\left(\mathrm{H}_{\mathrm{T}}\right)$ in the annatto collection was subdivided into components attributed to each locus separately (Table 4), and into components attributed to accessions and progenies (Table 5). Variance components associated with the 12 monomorphic enzyme loci at each hierarchical level were set to zero. Loci 6-Pgdh-2 and 6-Pgdh-3 made the highest impact to all variance levels. Sod-2 locus contributed mainly to the variance among accessions, given that it was polymorphic only in samples from Maranhão. Variability among plants within progenies $\left(\mathrm{H}_{\mathrm{C}}=0.0375\right)$ conferred the largest portion (58.4\%) of the total heterozygosity. This variation comprises the segregation at the polymorphic loci within family arrays,

Table 2. Frequences of alleles at polymorphic isozyme loci in the annatto accessions.

\begin{tabular}{lcccccc}
\hline Accessions & Alleles & \multicolumn{5}{c}{ Loci } \\
\cline { 3 - 7 } & & 6-Pgdh-2 & 6 -Pgdh-3 & Dia-2 & Sod-2 & Monomorphic \\
\hline CPATU & $\mathrm{a}$ & 0.433 & - & - & - & 1.000 \\
& $\mathrm{~b}$ & 0.567 & 0.442 & - & 1.000 & - \\
& $\mathrm{c}$ & - & 0.558 & 1.000 & - & - \\
\hline Campinas & $\mathrm{a}$ & 0.720 & 0.070 & 0.130 & - & 1.000 \\
& $\mathrm{~b}$ & 0.280 & 0.660 & - & 1.000 & - \\
& $\mathrm{c}$ & - & 0.270 & 0.870 & - & - \\
\hline Mato Grosso 1 & $\mathrm{a}$ & 0.680 & - & 0.120 & - & 1.000 \\
& $\mathrm{~b}$ & 0.320 & 0.680 & - & 1.000 & - \\
& $\mathrm{c}$ & - & 0.320 & 0.880 & - & - \\
\hline Mato Grosso 2 & $\mathrm{a}$ & 0.890 & 0.050 & 0.250 & - & 1.000 \\
& $\mathrm{~b}$ & 0.110 & 0.760 & - & 1.000 & - \\
& $\mathrm{c}$ & - & 0.190 & 0.750 & - & - \\
\hline Planaltina & $\mathrm{a}$ & 0.920 & 0.030 & 0.030 & - & 1.000 \\
& $\mathrm{~b}$ & 0.080 & 0.890 & - & 1.000 & - \\
& $\mathrm{c}$ & - & 0.080 & 0.970 & - & - \\
\hline Maranhão & $\mathrm{a}$ & 0.650 & - & - & 0.512 & 1.000 \\
& $\mathrm{~b}$ & 0.350 & 0.675 & 0.300 & 0.488 & - \\
& $\mathrm{c}$ & - & 0.325 & 0.700 & - & - \\
\hline
\end{tabular}

specially at the 6-PGDH loci, and variability between genes themselves.

The seeds used in this survey were not adequate for estimation of the outcrossing rate in annatto, because they were sampled from different natural populations. Nevertheless, the high frequency of heterozygote genotypes encountered at polymorphic loci $(\mathrm{Het}=0.28)$ indicates that annatto, is a predominantly open-pollinated species, it is an insect-pollinated plant. Fruits are not produced, when individual flowers are isolated with paper bags, but geitogamous crosses made by manual pollination were reported to be fertile (Pinheiro \& Almeida, 1992). Such results would be expected if there was temporal separation between the activity of male and female sexual organs in the flower (dichogamy). The reproductive biology of annatto remains to be studied.

The distribution of allozyme variation among progenies $\left(D_{C S}=0.0189\right)$ stands for the next major component (29.44\%) of $\mathrm{H}_{\mathrm{T}}$. Variability among progenies is accentuated, because parental trees represent separate original collection sites within each accession. The variability among accessions $\left(\mathrm{D}_{\mathrm{ST}}=0.0078\right)$ accounted for the remaining (12.15\%) of $\mathrm{H}_{\mathrm{T}}$.

Relationships between accessions are better illustrated in the UPGMA phenogram (Figure 2), constructed with the matrix of pairwise genetic distances (Nei, 1978) (Table 6). The longest branch in the phenogram separates Maranhão from all other accessions, mostly due to its private polymorphism at the Sod-2 locus (Table 2). The material from Northeastern Pará (CPATU collection) splits out in the next long branch of the phenogram, while the four accessions from Central Brazil form a distinct cluster.

Three major features emerge from survey on isozyme variability in annatto germplasm. The accessions in the CPAC collection (Campinas, Mato Grosso 1, Mato Grosso 2 and Planaltina) join into a distinct cluster, and

Table 3. Genetic variability parameters in the annatto germplasm collection: heterozygosity $(\mathrm{H})$ and average number of alleles at polymorphic loci (A), percentage polymorphic loci (P), observed (Het) and expected total heterozygosity $\left(\mathrm{H}_{\mathrm{T}}\right)$ in the annatto collection $^{(1)}$.

\begin{tabular}{|c|c|c|c|c|c|c|c|c|c|c|}
\hline \multirow[t]{2}{*}{ Accessions } & \multirow[t]{2}{*}{$\mathrm{N}$} & \multicolumn{5}{|c|}{$\mathrm{H}$} & \multirow[t]{2}{*}{$\mathrm{A}(\mathrm{SE})$} & \multirow[t]{2}{*}{$P$} & \multirow[t]{2}{*}{ Het (SE) } & \multirow[t]{2}{*}{$\mathrm{H}_{\mathrm{T}}(\mathrm{SE})$} \\
\hline & & 6-Pgdh-2 & 6-Pgdh-3 & Dia-2 & Sod-2 & $\mathrm{M}$ & & & & \\
\hline CPATU & 12 & 0.495 & 0.497 & 0.000 & 0.000 & 0.000 & $1.11(0.07)$ & 10.53 & $0.039(0.027)$ & $0.052(0.036)$ \\
\hline Campinas & 10 & 0.149 & 0.203 & 0.059 & 0.000 & 0.000 & $1.21(0.12)$ & 10.53 & $0.023(0.014)$ & $0.022(0.013)$ \\
\hline Mato Grosso 1 & 10 & 0.440 & 0.440 & 0.213 & 0.000 & 0.000 & $1.16(0.09)$ & 15.79 & $0.042(0.024)$ & $0.058(0.033)$ \\
\hline Mato Grosso 2 & 10 & 0.198 & 0.388 & 0.379 & 0.000 & 0.000 & $1.21(0.12)$ & 15.79 & $0.038(0.021)$ & $0.051(0.029)$ \\
\hline Planaltina & 10 & 0.407 & 0.492 & 0.228 & 0.000 & 0.000 & $1.21(0.12)$ & 15.79 & $0.043(0.024)$ & $0.059(0.034)$ \\
\hline \multirow[t]{2}{*}{ Maranhão } & 8 & 0.444 & 0.444 & 0.425 & 0.506 & 0.000 & $1.21(0.12)$ & 21.05 & $0.051(0.025)$ & $0.096(0.044)$ \\
\hline & 60 & 0.411 & 0.453 & 0.231 & 0.128 & 0.000 & $1.32(0.15)$ & 21.05 & $0.039(0.021)$ & $0.064(0.033)$ \\
\hline
\end{tabular}

${ }^{(1)} \mathrm{N}$ : sample size; M: monomorphics loci; SE: standard error. 
separate sharply from the Northern accessions (Maranhão and CPATU collections). Genetic distances between accessions in the CPAC collection are comparatively low. In spite of their geographic proximity, there is more genetic divergence between the Maranhão and CPATU collections, than between them and the geographically distant CPAC collection. In addition to allele frequency divergence at the 6-PGDH loci, progeny arrays from Maranhão segregated for Dia-2 and Sod2 alleles not present in the CPATU collection. Maranhão showed the highest heterozygosity $\left(\mathrm{H}_{\mathrm{T}}=0.096\right)$ among all examined accessions. The Central Brazilian accessions tended to show one predominant allele at the polymorphic loci. Allele frequencies were closer to intermediate values in the CPATU and Maranhão collections (Table 2), suggesting that genetic bottlenecks, and genetic drift, occurred during the dissemination of the species, from the Amazonian Basin towards the Central parts of the Country. The most Southern accession, Campinas, had in fact the lowest genetic variability $\left(\mathrm{H}_{\mathrm{T}}=0.022\right)$.

In Central Brazil, annatto is typically a backyard plant, cultivated as single trees or ornamental shrubs for domestic use of their seeds, in cuisine and folklore medicine. It is a common procedure to propagate these trees from seed samples exchanged within and between local communities. Genetic similarity, between CPAC accessions, probably reflects the small effective population size associated with this kind of cultivation.

Table 4. Total heterozygosity $\left(\mathrm{H}_{\mathrm{T}}\right)$, variance within progenies $\left(\mathrm{H}_{\mathrm{C}}\right)$, differences among progenies within accessions $\left(\mathrm{D}_{\mathrm{CS}}\right)$, and differences among accessions within the total collection $\left(\mathrm{D}_{\mathrm{ST}}\right)$, for the isozyme loci examined in annatto.

\begin{tabular}{lcccc}
\hline Loci & \multicolumn{4}{c}{ Genetic variance components } \\
\cline { 2 - 5 } & $\mathrm{H}_{\mathrm{T}}$ & $\mathrm{H}_{\mathrm{C}}$ & $\mathrm{D}_{\mathrm{CS}}$ & $\mathrm{D}_{\mathrm{ST}}$ \\
\hline 6-Pgdh-2 & 0.4104 & 0.2475 & 0.1204 & 0.0425 \\
6-Pgdh-3 & 0.4518 & 0.2869 & 0.1378 & 0.0271 \\
Dia-2 & 0.2307 & 0.1543 & 0.0535 & 0.0229 \\
Sod-2 & 0.1273 & 0.0238 & 0.0478 & 0.0557 \\
Monomorphic & 0.0000 & 0.0000 & 0.0000 & 0.0000 \\
\hline Total & 0.0642 & 0.0375 & 0.0189 & 0.0078 \\
\hline
\end{tabular}

Table 5. Percentage of the total heterozygosity $\left(\mathrm{H}_{\mathrm{T}}\right)$ attributed to variance within progenies $\left(\mathrm{H}_{\mathrm{C}}\right)$, differences among progenies within accessions $\left(\mathrm{D}_{\mathrm{CS}}\right)$, and differences among accessions within the total collection $\left(\mathrm{D}_{\mathrm{ST}}\right)$.

\begin{tabular}{lccccc}
\hline Heterozygosity components & \multicolumn{5}{c}{ Polimorphic loci } \\
\cline { 2 - 6 } & $6-\mathrm{Pgdh}-2$ & 6-Pgdh-3 & Dia-2 & Sod-2 & In set \\
\hline $\begin{array}{l}\text { Variability within progenies } \\
\left(\mathrm{H}_{\mathrm{C}} / \mathrm{H}_{\mathrm{T}}\right)\end{array}$ & 60.30 & 63.50 & 66.90 & 18.70 & 58.41 \\
$\begin{array}{l}\text { Variability among progenies within } \\
\text { accessions }\left(\mathrm{D}_{\mathrm{CS}} / \mathrm{H}_{\mathrm{T}}\right)\end{array}$ & 29.30 & 30.50 & 23.20 & 37.50 & 29.44 \\
$\begin{array}{l}\text { Variability among accessions within } \\
\text { the total collection }\left(\mathrm{D}_{\mathrm{ST}} / \mathrm{H}_{\mathrm{T}}\right)\end{array}$ & 10.40 & 6.00 & 9.90 & 43.80 & 12.15 \\
\hline
\end{tabular}

Nevertheless, the similarity could have been enhanced, to some extent, by gene flow among accessions during their multiplication in the field trial.

The sharp distinction between the three annatto collections examined in this survey is probably associated with ethnobotanical features. Annatto was traditionally used by indigenous people living in the Amazon Basin.

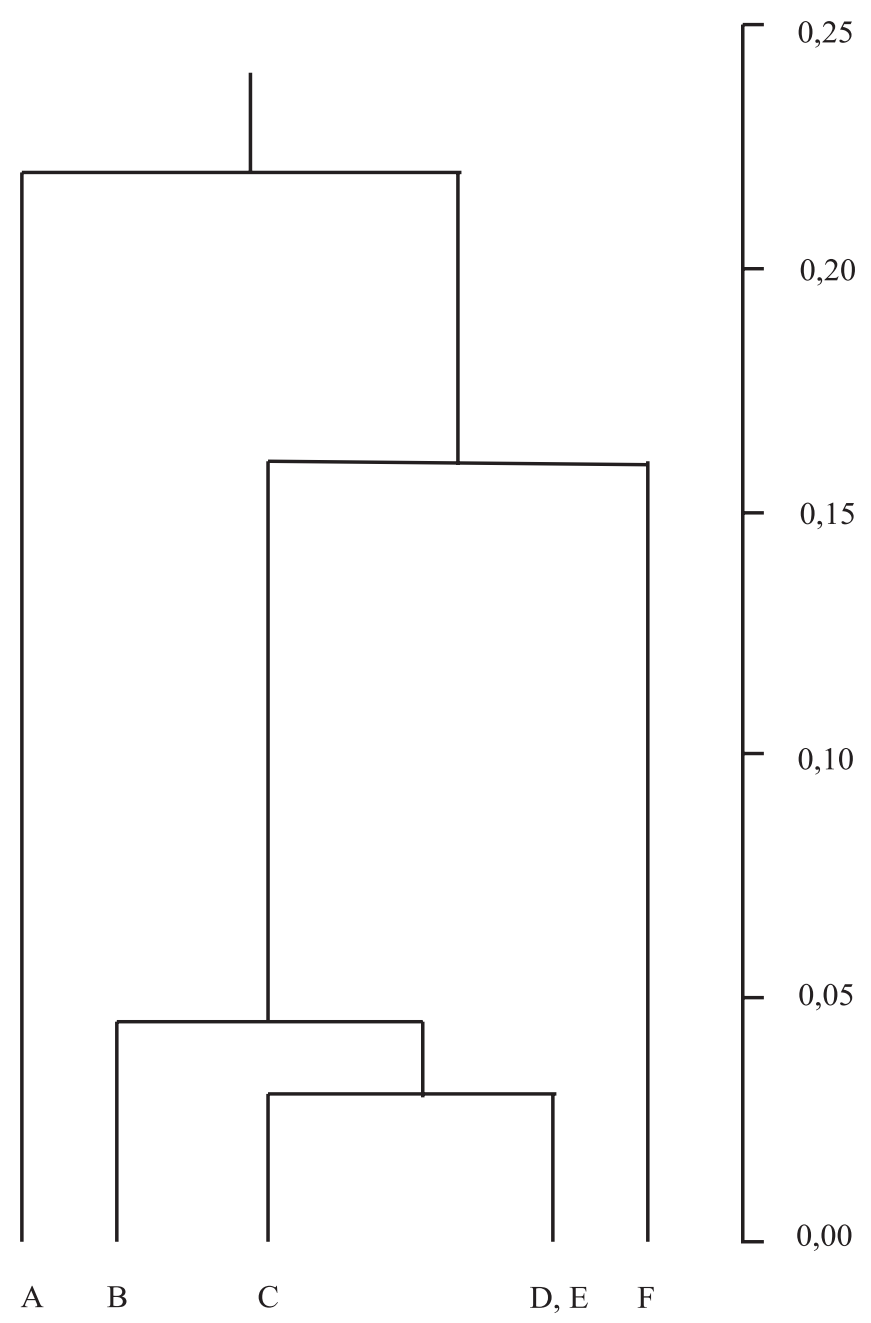

Figure 2. UPGMA phenogram of annatto accessions using Nei’s (1978) pairwise genetic distances among Maranhão (A), Planaltina (B), Mato Grosso 1 (C), Mato Grosso 2 (D), Campinas (E) and CPATU (F).

Table 6. Matrix of pairwise genetic distances (Nei, 1978) between annatto accessions based on allozyme variability.

\begin{tabular}{lcccccc}
\hline Accession & 1 & 2 & 3 & 4 & 5 & 6 \\
\hline 1 CPATU & - & & & & & \\
2 Campinas & 0.009 & - & & & & \\
3 Mato Grosso 1 & 0.007 & 0.000 & - & & & \\
4 Mato Grosso 2 & 0.021 & 0.002 & 0.004 & - & & \\
5 Planaltina & 0.025 & 0.005 & 0.006 & 0.003 & - & \\
6 Maranhão & 0.026 & 0.018 & 0.018 & 0.022 & 0.024 & - \\
\hline
\end{tabular}


Early nomadic hunter-gatherer populations must have dispersed annatto seeds within the Amazon region. Later, annatto seed was probably also traded among the indigenous tribes contributing to an even wider dispersion of the species. It would by expected to find maximum variability among Northern accessions of annatto. However, Northern accessions in our collection lack one or more alleles in loci 6-Pgdh-3 and Dia-2, present in the Central Brazilian accessions. These alleles must trace back to Northern locations not covered in our survey.

The separation between Northern accessions is specially interesting, because CPATU includes annatto accessions collected in Eastern Pará State, which is geographically adjacent to Maranhão State and at the fringes of the Amazon Basin. High morphological variation in fruit characteristics (shape, color, and pubescence) was found among annatto accessions from Maranhão. This Brazilian State encompasses the transition between the forested and humid Amazon Basin and the arid Northeastern region of Brazil. Such ecological boundary could favor microevolutionary processes, often reported for populations at the periphery of a species natural distribution. The genus Bixa consists of one or four species, depending on taxonomic interpretation (Heywood, 1993). The number of enzyme loci identified in our survey, and the migration rate of the isozyme activity zones in the gels, were very consistent over all samples, not providing evidence for taxonomic discontinuities in the annatto collection. However, further studies on the genetic resources in annatto should consider expanding the germplasm collection from Maranhão, use proper descriptors for the morphological variability, and include cytogenetic analysis of encountered variants to confirm their taxonomic status.

\section{Conclusions}

1. Percentage of polymorphic loci and the expected heterozygosity in annatto are low in comparison to other woody species.

2. Northern and Central Brazilian accessions of annatto are separated from UPGMA phenogram constructed with Nei's genetic distances.

3. There is a sharp genetic differentiation between the accessions from Maranhão and Pará States, despite their geographical proximity.

\section{References}

AGARWAL, S.; NATH, A.K.; SHARMA, D.R. Characterisation of peach (Prunus persica L.) cultivars using isozymes as molecular markers. Scientia Horticulturae, v.90, p.227-242, 2001.

ALFENAS, A.C.; BRUNE, W.; OLIVEIRA, J.R.; ALONSO, S.K.; SCORTICHINI, M. Extração de proteínas para eletroforese. In: ALFENAS, A.C. (Ed.). Eletroforese de isoenzimas e proteínas afins: fundamentos e aplicações em plantas e microorganismos. Viçosa-MG: Ed. UFV, 1998. p.85-114.

CLAYTON, J.W.; TRETIAK, D.N. Amine-citrate buffers for pH control in starch gel electrophoresis. Journal of the Fisheries Research Board of Canada, v.29, p.1169-1172, 1972.

GUO, W.; WANG, R.; ZHOU, S.; ZHANG, S.; ZHANG, Z. Genetic diversity and clonal structure of Phragmites australis in the Yellow River delta of China. Biochemical Systematics and Ecology, v.31, p.1093-1109, 2003.

HAKIM-ELAHI, A. Temporal changes in population structure of the slender wild oat (Avena barbata) as measured by allozyme polymorphisms. 1980. 124p. Tese (Ph.D.) - Universidade da Califórnia, Davis.

HAMRICK, J.L.; LOVELESS, M.D. Isozyme variation in tropical trees: procedures and preliminary results. Biotropica, v.18, p.201207, 1986.

HARTL, D.L.; CLARK, A.G. Principles of population genetics. Suderland: Sinauer Associates, 1997. 324p.

HEYWOOD, V.H. Flowering plants of the world. New York: Oxford University Press, 1993. 426p.

LEE, S.L.; KEVIN, K.S.N.; SAW, L.G.; NORWATI, A.; SALWANA, M.H.S.; LEE, C.T.; NORWATI, M. Population genetics of Intsia palembanica (Leguminosae) and genetic conservation of virgin jungle reserves in Peninsular Malaysia. American Journal of Botany, v.89, p.447-459, 2002.

LINGERFELT, C.W. O urucum como cultura alternativa. Informativo Rural, v.14, p.20-24, 1984.

MORAIS, O.M.; SÃO JOSÉ, A.R.; REBOUÇAS, T.N.H.; ATAÍDE, E.M. Mejoramiento genético del achiote en Brasil. Revista Brasileira de Corantes Naturais, v.3, p.109-111, 1999.

MORAN, G.F.; BELL, J.C. Eucalyptus. In: TANKSLEY, S.D.; ORTON, T.J. (Ed.). Isoenzymes in plant genetics and breeding: Part B. Amsterdan, Elsevier, 1983. p.423-441.

NEI, M. Estimation of average heterozygosity and genetic distance from a small number of individuals. Genetics, v.89, p.583-590, 1978.

PINHEIRO, A.L.; ALMEIDA, E.C. Avaliação de um híbrido artificial obtido entre duas variedades de urucum (Bixa orellana L.) em Viçosa - Minas Gerais. Revista Brasileira de Corantes Naturais, v.1, p.31-35, 1992.

PLOTKIN, M.J. Tales of a Shaman's apprentice. New York: Penguin Books, 1993. 233p.

POULIK, M.D. Starch gel electrophoresis in a discontinuous system buffers. Nature, v.180, p.1477-1479, 1957. 
PÓVOA, M.E.B. Extração do corante de urucum (Bixa orellana L.) com diversos solventes. Revista Brasileira de Corantes Naturais, v.1, p.153-157, 1992.

PRENTICE-HERNANDEZ, C.; RUSIG, O. Extrato de urucum (Bixa orellana L.) obtido utilizando álcool etílico como solvente. Arquivos de Biologia e Tecnologia, v.35, p.63-74, 1992.

RAMALHO, R.S.; PINHEIRO, A.L.; DINIZ, G.S. Informações básicas sobre a cultura e utilização do urucum (Bixa orellana L.). Viçosa: UFV/Conselho de Extensão, 1987. 22p. (Informe Técnico, 59).

SANTOS, A.; SÃO JOSÉ, A.R.; REBOUÇAS, T.N.H. Doenças do urucum. Revista Brasileira de Corantes Naturais, v.4, p.97-102, 2000.

SCANDALIOS, J.G. Genetic control of multiple molecular forms of enzymes in plants: a review. Biochemical Genetics, v.3, p.37-79, 1969.
SHARMA, K.; JONES, D.L.; FORSTER, P.I. Genetic differentiation and phenetic relatedness among seven species of the Macrozamia plurinervia complex (Zamiaceae). Biochemical Systematics and Ecology, v.32, p.313-327, 2004.

SNEATH, P.H.A.; SOKAL, R.R. Numerical taxonomy. San Francisco: Freeman, 1973. 573p.

SWOFFORD, D.L.; SELANDER, R.B. Biosys-1: a FORTRAN program for the comprehensive analysis of electrophoretic data in population genetics and systematics. Journal of Heredity, v.72, p.281-283, 1981.

VILARES, A.S.; SÃO JOSÉ, A.R.; REBOUÇAS, T.N.H.; SOUZA, I.V.B. Estudo da biologia floral de urucuzeiro (Bixa orellana L.). Revista Brasileira de Corantes Naturais, v.1, p.101-105, 1992. WEEDEN, N.F.; WENDEL, J.F. Genetics of plant isozymes. In: SOLTIS, D.E.; SOLTIS, P.S. (Ed.). Isozymes in plant biology. Oregon: Discorides Press, 1989. p.46-72. 